\title{
"Não queremos ser americanizados"
}

\section{Flávio Limoncic*}

CORRÊA, Larissa Rosa. Disseram que voltei americanizado. Relações sindicais BrasilEstados Unidos na ditadura militar. Campinas: Editora da Unicamp, 2017.

Palavras-chave: Sindicalismo; Brasil e Estados Unidos; ditadura militar.

Keywords: Trade unionism; Brazil and EUA; dictatorship.

No ambiente de radicalização do debate público brasileiro que vem ocorrendo desde o impeachment de Dilma Rousseff, em maio de 2016, o regime civil-militar instaurado em 1964 tem sido reivindicado por segmentos importantes, e talvez crescentes, da sociedade. Na nova memória social que em torno dele se constrói, o governo dos generais surge como um tempo de ordem, progresso, segurança e valores morais em contraposição ao desarranjo político, à estagnação econômica, ao crescimento da criminalidade e à crise dos valores da família e da religião. A conjuntura política exige, portanto, uma compreensão mais profunda do regime inaugurado com a derrubada de João Goulart. Para tal, o livro de Larissa Rosa Corrêa, Disseram que voltei americanizado. Relações sindicais Brasil-Estados Unidos na ditadura militar, fruto de sua tese de doutorado em História defendida na Universidade Estadual de Campinas, em 2013, constitui contribuição fundamental. Mas a obra de Larissa não se resume à sua evidente relevância política. A partir de uma pesquisa de fontes inédita na amplitude e variedade - relatórios, cartas, entrevistas, imprensa etc., tanto brasileiros quanto norte-americanos - a autora discute a ação da central sindical norte-americana American Federation of LaborCongress of Industrial Organizations (AFL-CIO) no Brasil dos anos 1960 e 1970. Como resultado, do ponto de vista estritamente historiográfico, o livro representa uma das mais criativas e instigantes reflexões acerca do regime civil-militar de 1964 e do sistema brasileiro de regulação do trabalho.

Não há novidade no fato apontado pela autora de que a AFL-CIO atuou com o apoio da CIA para combater o comunismo no seio do movimento sindical brasileiro. Novidade há, e muita, na análise minuciosa que Larissa Rosa Corrêa realiza a respeito da atuação do Instituto para o Desenvolvimento do Sindicalismo Livre (ladesil), ligado à AFL-CIO, no Brasil. Por meio de intercâmbios, viagens aos Estados Unidos, bolsas de estudo, publicações e cursos, a AFL-CIO buscou, em vão, contribuir para a substituição da estrutura sindical corporativa brasileira por um modelo contratualista de relações de trabalho, o assim chamado sindicalismo livre e democrático.

Nas razões apontadas pela autora para explicar o “em vão" reside, justamente, uma das principais riquezas do livro.

\footnotetext{
* Departamento de História, Universidade Federal do Estado do Rio de Janeiro.
} 
Profunda conhecedora tanto da historiografia do trabalho no Brasil quanto da do regime civil-militar de 1964 e dos debates teóricos acerca da regulação do trabalho, Larissa Rosa Corrêa mostra como os diferentes projetos aninhados no regime - do economicamente liberal de Castelo Branco ao desenvolvimentista de Costa e Silva, Médici e Geisel - lidaram de maneiras diversas com a ação do ladesil. Da mesma forma, os sindicalistas brasileiros abordaram de distintas formas a mensagem do sindicalismo "livre e democrático". Como resultado, se por um lado o regime civil-militar promulgou Atos Institucionais com vistas à substituição do ordenamento liberal-democrático de 1946, por outro manteve quase inalterado o legado varguista no sistema de regulação das relações de trabalho, limitando-se a introduzir o fim da estabilidade no emprego e o FGTS. Para a autora, a estrutura corporativa, ao permitir tanto negociações coletivas como a intervenção do Estado na vida sindical e na formação dos salários, revelou-se plástica o suficiente para coexistir com regimes políticos autoritários - não só o varguista, mas também o de 1964 - e liberal-democráticos, como os de 1946 e 1988. Não menos importante, a autora aponta que a estrutura corporativa era percebida por importantes segmentos do movimento sindical brasileiro como uma moldura legal que lhes garantia uma série de direitos e proteções, estando profundamente arraigada na cultura do mundo do trabalho no Brasil. Portanto, o regime civil-militar manteve funcionando os contornos gerais de tal estrutura, ainda que utilizando-a como instrumento do arrocho salarial. Em tal cenário, a pregação da AFL-CIO não tinha como encontrar terreno fértil. Indicativo de tal fato é que se o sindicalismo do $A B C$ paulista fazia duras críticas à estrutura corporativa na conjuntura dos anos 1970 com um vocabulário próximo ao contratualismo da AFL-CIO, anos depois passaria a ser defensor da CLT.

O contratualismo da AFL-CIO, contudo, poderia ter sido alvo de análise um pouco mais detida por parte da autora. Assim como o corporativismo brasileiro resultou não tanto da ação demiúrgica de um Estado autoritário do que de um complexo processo social e político que acabou por atribuir centralidade à burocracia estatal, o contratualismo privado norte-americano não resultou do conservadorismo intrínseco dos trabalhadores norte-americanos. Pelo contrário, foi construído ao longo de décadas de acirrada luta sindical não só contra os patrões, mas também contra o Estado norte-americano. A AFL-CIO surgiu em 1955, como resultado da união de duas centrais sindicais, a AFL e o $\mathrm{ClO}$. A primeira, fundada em 1886, é usualmente tida como a mais perfeita tradução do conservadorismo e do contratualismo do sindicalismo norte-americano. No entanto, a AFL nasceu fazendo a crítica das relações de trabalho assalariadas e seu contratualismo anti-estatal foi se constituindo como uma reação à ação do Poder Judiciário. De fato, desde 1806, primeiro através da doutrina da conspiração, e a partir de 1877, com labor injunctions, os tribunais sistematicamente desarticularam os esforços associativos dos trabalhadores norte-americanos. Já o ClO, fundado em 1935 como uma dissidência da AFL, dela discordava não apenas em função do perfil sindical - se profissional, como queria a AFL, se industrial, defendida pelo $\mathrm{ClO}$ como também em razão de sua defesa do papel ativo do Estado na regulação dos mercados, inclusive o de trabalho. Por conta de seu contratualismo anti-estatal, a AFL foi uma dura crítica do New Deal de Franklin D. Roosevelt - cujas agências administrativas tinham características próximas ao corporativismo - ao passo que o CIO forneceu uma forte base de apoio político a Roosevelt. A união entre AFL e CIO, em 1955, não obscureceu completamente tais clivagens, e muito embora a AFL-CIO tenha se tornado de fato crescentemente conservadora sob a liderança 
de George Meany (que chegou a afirmar que suas posições não eram muito diferentes das da National Association of Manufacturers), lideranças como Walther Reuther, oriundas do $\mathrm{ClO}$, continuaram a defender concepções de regulação do mercado de natureza mais próxima à social-democracia europeia até a década de 1960. Tais clivagens no seio da AFL-CIO não são aprofundadas por Larissa Rosa Corrêa, que centra sua análise justamente na atuação da liderança de Meany.

Tal questão não compromete, em absoluto, a qualidade do trabalho, que, afinal, está mais preocupado com o Brasil do que com os Estados Unidos. E, no que se refere ao Brasil, Larissa analisa em profundidade algumas das principais discussões e atores do cenário sindical brasileiro e do regime civil-militar das décadas de 1960 e 1970, como os projetos de Evaristo de Moraes Filho e Arnaldo Sussekind para a reforma das relações de trabalho e as surpreendentes posições de Jarbas Passarinho sobre as relações entre trabalhadores e patrões, baseadas no solidarismo cristão. Particularmente saborosas são as passagens nas quais a autora narra as críticas de sindicalistas norte-americanos ao autoritarismo do regime civil-militar brasileiro e as viagens de sindicalistas brasileiros aos Estados Unidos. Quando Arthur Martins Filho, da Federação Nacional dos Empregados Vendedores e Viajantes do Comércio do Rio de Janeiro, vê neve pela primeira vez em Nova York, não há como não lembrar da cena de Bye Bye Brasil em que Lorde Cigano (interpretado por José Wilker), ao fazer nevar, afirma estar realizando o sonho de todos os brasileiros.

Em suma, Disseram que voltei americanizado constitui obra indispensável para o aprofundamento da reflexão não apenas da resiliência do sistema corporativo brasileiro, como também do regime civil-militar de 1964. Não menos importante, constitui também contribuição fundamental para a discussão da conjuntura ora vivida no Brasil, em que a CLT é posta em xeque em nome da primazia do contratado sobre o legislado. Talvez seja o caso de fazer hoje o que fizeram os trabalhadores brasileiros nos anos 1960 e 1970 analisados por Larissa e dizer, em alto e bom som, que não queremos ser americanizados. 
